\title{
Expression of Perforin Gene for Early Development of Nephrons in Olive Flounder (Paralichthys olivaceus)
}

\author{
Hyun Yang, Young Mee Lee, ${ }^{\dagger}$ Jeong-Ho Lee, Jae Koo Noh, Hyun Chul Kim, Choul-Ji Park, \\ Jong-Won Park, In Joon Hwang and Sung Yeon Kim \\ Genetics and Breeding Research Center, NFRDI, Geoje 656-842, Republic of Korea
}

\begin{abstract}
The innate immune system is the only defense weapon that invertebrates have, and it is the fundamental defense mechanism for fish. The innate immune response is important in newly hatched flounders because it is closely involved in the initial feeding phase, which is why it is essential for survival during the juvenile period. The expression analysis of genes involved in the innate immune response in the olive flounder (Paralichthys olivaceus) in the days after hatching is incomplete. Therefore, we have begun to examine the expression patterns of genes specifically induced during the development of the innate immune system in newly hatched flounders. Microscopic observation showed that pronephron formation corresponded with the expression of perforin-encoding gene. These results suggest that perforin plays a vital role in the innate immunity of the kidney during developmental stages. Perforin expression was strong at the start of the development of the innate immune response, and continued throughout all the development stages. Our findings have important implications with respect to perforin's biological role and the evolution of the first defense mechanisms in olive flounder. Further studies are required to elucidate the perforin-mediated innate immunity response and to decipher the functional role of perforin in developmental stages.
\end{abstract}

Key words : Perforin, Innate immunity, Development, Gene expression, Pronephron, Olive flounder

\section{INTRODUCTION}

The olive flounder (Paralichthys olivaceus) is one of the most important fish species and constitutes more than $50 \%$ of the total fish community biomass. Therefore, it plays an important role in aquaculture and fisheries in South Korea. In most oviparous fish, including the olive flounder, larval survival depends upon the timely response of the innate immune system. It is customary to divide the immune system into the innate (nonspecific) and the acquired (specific) immune systems. However, an increasing body of evidence regarding fish and mammalian immunology shows that these are actually combinational systems (Fearon
\& Locksley, 1996).

The innate immune response generally precedes the adaptive response, activates and determines the nature of the adaptive response, and cooperates with the adaptive response in the maintenance of homeostasis (Fearon, 1997). By definition, the innate immune system's recognition of nonself is mediated by germline-encoded pattern recognition proteins/receptors that identify patterns of molecular characteristic of microbes. These molecules include polysaccharides, lipopolysaccharides (LPSs), peptidoglycans, bacterial DNA, double-stranded viral RNA, and other molecules not normally found on the surface of multicellular organisms (Medzhitov \& Janeway, 1998; Medzhitov \& Janeway, 2002; Elward

\footnotetext{
Manuscript received 20 November 2013, Received in revised form 2 December 2013, Accepted 10 December 2013

† Corresponding Author : Jeong-Ho Lee, Genetics and Breeding Research Center, NFRDI, Geoje 656-842, Republic of Korea. Tel. : +82-55-639-5811, Fax : +82-55-639-5809 E-mail : jhlee7124@korea.kr

This is an Open Access article distributed under the terms of the Creative Commons Attribution Non-Commercial License(http://creativecommons. org/licenses/by-nc/3.0) which permits unrestricted non-commercial use, distribution, and reproduction in any medium, provided the original work is properly cited.
} 
\& Gasque, 2003). This characteristic of the innate system is fundamentally different from the recognition arrangement of the acquired immune system and has its roots in ancient evolutionary history, or as far back as the early metazoa (Porifera), which evolved around a billion years ago. The origin of the acquired immune system can be traced back to the origin of the jawed vertebrates about 450 million years ago, with the advent of the recombination activating genes (RAGs) (Wilson et al., 1994). Their appearance signaled the onset of rearrangement of the immune globulin (Ig) super-family genes, the B-cell and T-cell receptors, and the MHC classes, leading to the possible recognition of practically unlimited numbers of antigenic epitopes (Beck \& Habicht, 1996; Du Pasquier, 2001). Increased diversity and advanced affinity maturation and memory have perfected the evolution of the acquired system as seen in mammals. However, there are several examples of the innate immune systems of fish being more active and showing more diversity than comparable components of mammalian species (Sunyer et al., 1997).

Cytotoxic T lymphocytes (CTLs) and natural killer (NK) cells play important roles in immune defense by destroying infected tissues (Crowe, 1999). These cells induce apoptosis by two pathways (Henkart, 1994). One pathway involves the engagement of target cell death receptors through the Fas/Fas ligand (Barry \& Bleackley, 2002), while the other, the granule-exocytosis pathway, involves perforin and granzymes (Peters et al., 1991; Liu et al., 1994). Perforin has been suggested to be one of the effectors of cellmediated killing (Lowin et al., 1994; Clark et al., 1995; Trapani \& Smyth, 2002). Perforin is expressed by CTLs and NK cells, and is stored in cytoplasmic granules of CTLs and NK cells, but is not found in helper T-cells or other immune cells (Lowrey et al., 1989). Perforin monomers insert themselves into the plasma membrane of target cells, polymerize into pore-forming aggregates in the presence of calcium, and form transmembrane channels. Pores formed by perforin range from 5 to $20 \mathrm{~nm}$ in internal diameter and cause osmotic lysis of the target cells (Masson \& Tschopp, 1985; Athanasopoulou et al.,
2009). The pores also allow a family of proteases, known as granzymes, to enter the target cell and induce apoptosis (Tschopp \& Nabholz, 1990; Grossman et al., 2004).

On searching through a national center for biotechnology information database (NCBI), we found a sequence similar to perforin. However, the temporal expression patterns of this perforin-like gene during the developmental stages and in normal tissues of olive flounder are unknown. The purpose of this study was to examine the expression patterns of perforin in normal tissues of the olive flounder and during the development of the innate immune system in newly hatched olive flounders.

\section{MATERIALS AND METHODS}

\section{Fish breeding and RNA purification}

All experimental fish were raised at Genetics and Breeding Research Center, National Fisheries Research and Development Institute (NFRDI) and maintained in 10 tons flow through tank at $20 \pm 1^{\circ} \mathrm{C}$ under a natural photoperiod. Different stages of embryo $(0.92 \pm 0.02 \mathrm{~mm})$, larvae $(2.49 \pm 0.34 \mathrm{~mm})$ and juvenile $(3.5 \pm 0.45 \mathrm{~mm})$ development were described from fish kept at $20^{\circ} \mathrm{C}$ in the tank. Several tissues of 2 years $(38 \mathrm{~cm} \pm \mathrm{SEM})$ old were used to in olive flounder. The samples of 10 fish were randomly collected and frozen in $70^{\circ} \mathrm{C}$ deep freezer until isolation of total RNA. Pooled eye tissues were homogenized for $20 \mathrm{sec}$ with Trizol reagent (Invitrogen, Carlsbad, CA, USA).

\section{Microscopic analysis}

Larvae were examined as previously described, fixed at room temperature, in 2.5\% glutaraldehyde (Polysciences, Inc., Warrington, PA) in $0.1 \mathrm{M}$ sodium cacodylate- $\mathrm{HCl}$ buffer, $\mathrm{pH}$ 7.3, for $10 \mathrm{~min}$, and post fixed in 1\% paraformaldehyde (Sigma-Aldrich, CA, USA) in the same buffer, for 20 min with $1 \%$ uranyl acetate for $1 \mathrm{~h}$ and ethanol dehydration. The samples were examined under a stereo microscope (ZEISS CL1500 ECO Jena, Germany) imaging system at $\times 400$ magnification of development was determined. 
3. Traditional reverse transcription-polymerase chain reaction ( $R T-P C R$ )

Total RNA was extracted using the Trizol Reagent (Invitrogen, Carlsbad, CA, USA) according to the manufacturer's protocol. DNase-I (Sigma-Aldrich, CA, USA) was treated for removing genomic DNA contamination from RNA for $30 \mathrm{~min}$ at $37^{\circ} \mathrm{C}$. The RNA samples were extracted with phenol/chloroform to inactivate the DNase I. RNA concentration was measured with spectrophotometer (Gene-Quant, Pharmacia Biotech), quality of RNA was checked by gel electrophoresis (1\% agarose gel) and stored at $-80^{\circ} \mathrm{C}$ until further use. RNA (100 ng) from each sample was transcribed to cDNA using Transcriptor First Strand cDNA synthesis kit (Roche Ltd., SWISS). The amplification was performed with AmpliTag Gold DNA Polymerase (Applied Biosystems., CA, USA) and My cycler Thermal Cycler (Bio-Rad Laboratories Inc., Hercules, CA, USA) using the following parameters: denaturation at $95^{\circ} \mathrm{C}$ for 10 minutes and 35 cycles of reactions of denaturation at $98^{\circ} \mathrm{C}$ for $10 \mathrm{~s}$, annealing at $58^{\circ} \mathrm{C}$ for $30 \mathrm{~s}$, and elongation at $72^{\circ} \mathrm{C}$ for $45 \mathrm{~s}$. An aliquot of each PCR product was subjected to $1.5 \%(\mathrm{w} / \mathrm{v})$ agarose gel electrophoresis and visualized by staining with ethidium bromide. The 5' forward and 3' reverse-complement PCR primers for amplification of each gene were as follows: Perforin (5'-AGCATGTGAGCAAGTTCTGTCT-3') and (5'-GGC ATGACGGGACACATAC-3'), $\beta$-Actin (5'-TGATGAA GCCCAGAGCAAGA-3') and (5'-CTCCATGTCATCCC AGTTGG-3'). Relative amount of each messenger RNA was quantified by dividing by density of housekeeping gene (Gene bank, HQ 386788.1).

\section{Real-time-PCR analysis}

To evaluate arrestin mRNA levels, these primers were specifically designed to detect and quantify cDNA sequences without detecting genomic DNA. The Fast-Start DNA Master SYBR Green I (Roche Ltd., SWISS) was used as fluorescent reporter dye to detect amplification products in 7500 Fast Real Time PCR System (Applied Biosystems Inc. Carlsbad, CA, USA) using the following cycling conditions: denaturation at $95^{\circ} \mathrm{C}$ for 10 min and 40 cycles of reactions of denaturation at $95^{\circ} \mathrm{C}$ for $10 \mathrm{~s}$, annealing at $58^{\circ} \mathrm{C}$ for $30 \mathrm{~s}$, and elongation at $72^{\circ} \mathrm{C}$ for $30 \mathrm{~s}$. Each sample was tested in triplicate to ensure statistical significance. The PCR efficiency (E\%) of gene was derived from perforin (96.2\%) and $\beta$-Actin (95.4\%) respectively. The relative quantification of perforin gene expression was performed using the comparative $C_{t}$ method. The $C_{\mathrm{t}}$ value is defined as the point where a statistically significant increase in the fluorescence has occurred. The number of PCR cycles $(C \mathrm{t})$ required for the ROX intensities to exceed a threshold just above background was calculated for the test and reference reactions. In all experiments, $\beta$-Actin was used as the endogenous control. Results were analyzed in a relative quantitation study with the vehicle treated.

\section{Statistical analysis}

Data were analyzed using Sigma plot for Windows (Jandel Scientific, San Rafael, CA, USA). For unpaired matched comparative analysis of multiple groups, an analysis of variance (ANOVA) was performed. Data that did not meet normality assumptions were subjected to one way ANOVA on ranks, and then pair wise comparisons were made using the Student-Newman-Keuls (SNK) method.

\section{RESULTS}

1. Early development of nephrons in olive flounder (Paralichthys olivaceus)

To determine the origin of the two-nephron system during the early stages of development in the olive flounder, we first observed the lateral side of live olive flounder larvae 1 day after hatching (DAH) by using a dissecting stereo microscope. At this stage, the eye, yolk, anus, and the pronephric tubules and ducts attain their normal size and shape. The initial morphological changes that lead to nephron formation were clearly visible as early as 1-DAH in olive flounder larvae (Fig. 1A). The pronephros in 1-DAH larvae consists of a glomerulus, pronephric tubules, and paired 

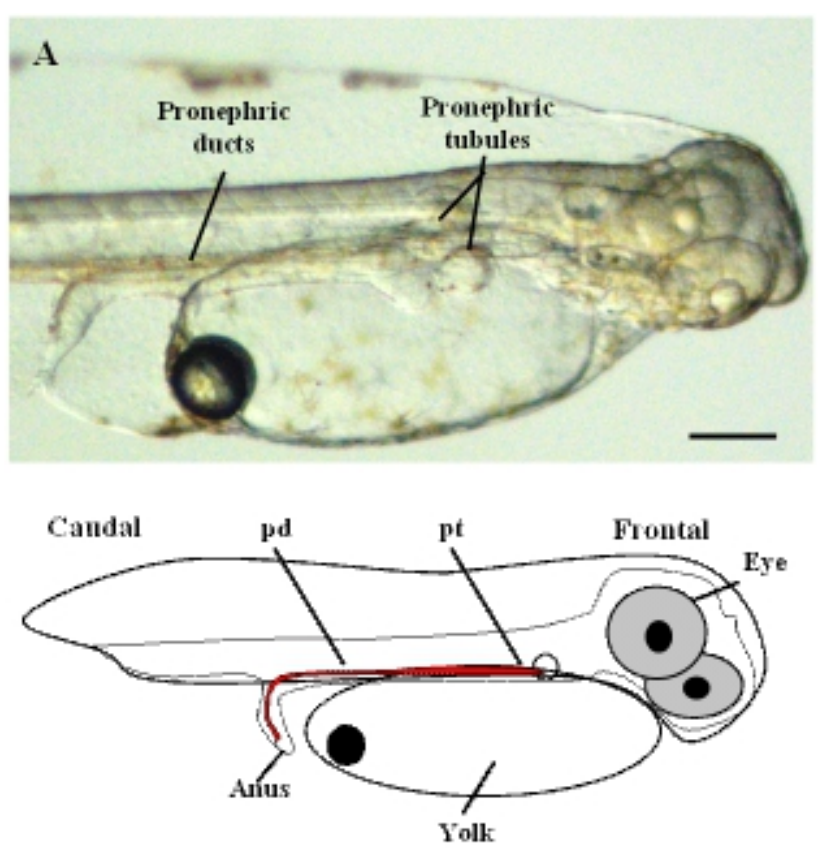

Fig. 1. Development of pronephron system formation of the olive flounder (Paralichythys olivaceus). The experiment was fertilized eggs of olive flounder from the tank, oxygen supply and maintains a temperature of $20 \mathrm{C}$. Schematic dorsal view of the brain and eyes of a flat fish with key features labeled. (A) Photograph was shown during after hatching for 1 day, Magnification: $\times 400$. The following structures can be identified in development olive flounder larvae under dissecting stereomicroscopes (pd, Pronephric ducts; pt, Pronephric tubules). Scale bar, $300 \mu \mathrm{m}$.

pronephric ducts. Fig. 1A shows the glomerulus under the notochord at 1-DAH and the pronephric tubules extending laterally to connect with the pronephric ducts, which function as the collecting system.

The glomerulus and tubules lie below the third somite and just caudal to the pectoral fins. The complete system, consisting of the paired pronephric tubules and ducts can be visualized in 3-DAH larvae (Takeyasu et al., 1988).

\section{Expression analysis of the perforin gene during} nephron development

The expression of a newly identified perforin was detected in olive flounder embryos and larvae by using traditional reverse transcription-polymerase chain reaction (RT-PCR). Although expression of the perforin gene was
A

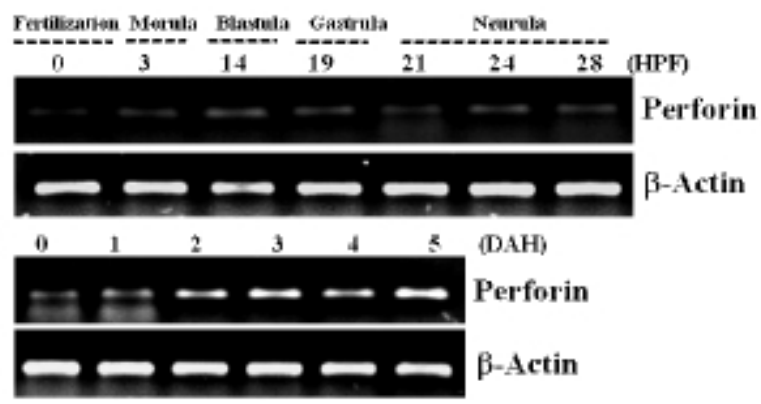

B

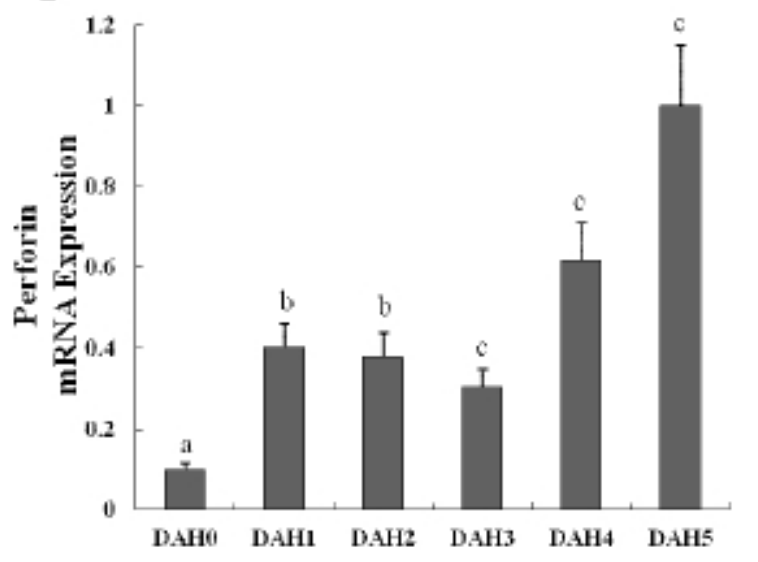

Fig. 2. Expression of perforin gene induces in the development stage. (A) The experiment was flounder fertilized eggs from the tank, oxygen supply and maintain a temperature of $20^{\circ} \mathrm{C}$. Embryo and larva were harvested during hours post fertilization (HPF) and days after hatching (DAH) for the indicated periods. The RNA extracted and perforin was analyzed by RT-PCR method. (B) The mRNA expression of perforin was analyzed by real-time PCR. Different letters over each bar with the standard deviation represent significant differences one group according to unpaired matched comparisons $(p<0.05)$.

not detectable post-fertilization, it was detected from 1-DAH and increased continuously up to 5-DAH (Fig. 2A). Perforin expression in olive flounder at various stages of development and in various tissues was examined using real time PCR (Fig. 2B). Perforin was similarly expressed from 1-DAH to 5-DAH. In 2-year-old flounders, perforin mRNA was found to be expressed at similar levels in the kidneys, spleen, and gills, but was not expressed in the muscles, liver, eyes, fins, and brain (Fig. 3A, 3B). Expression of perforin increased with age in the primary immune organs, but decreased with age in the non-immune organs. 
A

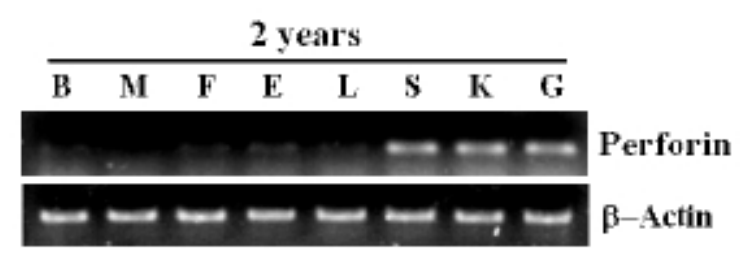

B

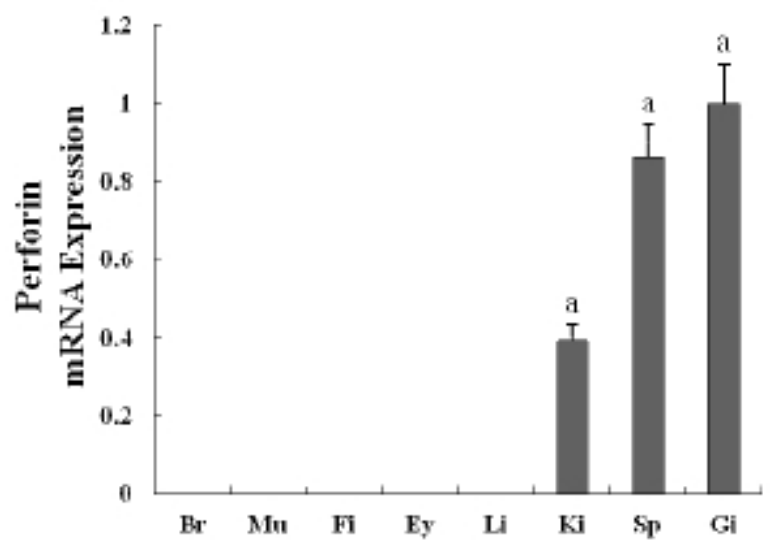

Fig. 3. Expression analysis of purforin gene induces from several tissues in the olive flounder. Experiments are examined with various periods of adult fish. (A) Perforin gene expression from the segmental tissue (B: brain, M: muscle, F: fin, E: eye, L: liver, S: spleen, K: kidney, G: gill) for the olive flounder at 2 years of age were analyzed using RT-PCR. (B) The mRNA expression of perforin was analyzed by real-time PCR. Different letters over each bar with the standard deviation represent significant differences one group according to unpaired matched comparisons $(p<0.05)$.

These results show that perforin is expressed during the development of the immune system, which suggests that perforin plays a role in the immune mechanism in the early stages of development.

\section{DISCUSSIONS}

Previous studies have established that the pronephric ducts are fully formed and patent to the exterior within $24 \mathrm{~h}$ post-fertilization in zebra fish (Kimmel et al., 1990; Kimmel et al., 1995). However, the formation of the pronephric tubules and glomeruli has not been described in any study. Guided by the position of the mature pronephric nephron, we examined the cellular structures medial to the anterior tips of the pronephric ducts at various time points to define the stages of nephron formation. At 1-DAH, a nephron primordium was visualized ventral to the third somite (Fig. 1A). The primordium at this stage appears as an infolding of the coelomic lining, with a clear opening to the coelom. This opening to the coelom could be considered the equivalent of a nephrostome observed in other fish species and in mature amphibian pronephroi (Drummond et al., 1998; Tran et al., 2007).

Most of the generative and secondary lymphoid organs present in mammals are also found in fish, except the lymphatic nodules and the bone marrow (Horton \& Summers, 2009). Instead, the head kidney, which is aglomerular, assumes hemopoietic functions and, unlike in higher vertebrates, is the principal immune organ responsible for phagocytosis, antigen processing, and formation of IgM and immune memory through melanomacrophagic centers (Meseguer et al., 1995; Deivasigamani, 2007). The kidney in fish is a diverse, Y-shaped organ that is placed along the body axis. The lower part is a long and is situated parallel to the vertebral column, most of which works as the renal system. The active immune part, the head kidney or the pronephros, is formed by two $\mathrm{Y}$ arms, which penetrate underneath the gills. In fish, this structure has a unique feature: the head kidney is also an important endocrine organ, homologous to mammalian adrenal glands, that releases corticosteroids and other hormones (Castillo et al., 2009). Thus, the head kidney is an important organ with key regulatory functions and is the central organ for immune-endocrine interactions and even neuroimmunoendocrine connections (Tsujii \& Seno, 1990; Abdel-Aziz et al, 2012).

As in previous reports, we also found that perforin is expressed during pronephron formation and in the lymphoid organs and tissues of 2-year-old flounders. Real-time PCR data showed that perforin mRNA is expressed and is detectable until 5-DAH (Fig. 2, Fig. 3). An interesting feature of the cytotoxic-perforin gene expression is its relatively high expression in the endocrine and lymphoid organs. Nephron formation was observed in the early developmental stages, and the perforin gene was signifi- 
cantly expressed in these stages, suggesting that perforin may play a crucial role in the larval immune system.

In conclusion, expression analysis of cytotoxic perforin during pronephron formation might provide information that could be useful in understanding the initial immune responses and growth of olive flounder larvae. Further functional studies on this gene will help elucidate the molecular regulatory mechanisms and the immune signaling pathways involved in pronephron formation in olive flounder, as well as identifying the perforin-mediated genes.

\section{ACK NOWLEDGEMENTS}

This work was supported by a grant from the National Fisheries Research and Development Institute (NFRDI), contribution number RP-2013-BT-107.

\section{REFERENCES}

Abdel-Aziz SH, Abdu SB, El-Sayed Ali T, Fouad HF (2012) Haemopoiesis in the head kidney of tilapia, Oreochromis niloticus (Teleostei: Cichlidae): a morphological (optical and ultrastructural) study. Fish Physiol Biochem 36:323-336.

Athanasopoulou S, Marioli D, Mikrou A, Papanastasiou AD, Zarkadis IK (2009) Cloning and characterization of the trout perforin. Fish Shellfish Immunol 26:908912.

Barry M, Bleackley RC (2002) Cytotoxic T lymphocytes: all roads lead to death. Nat Rev Immunol 2:401-409.

Beck G, Habicht GS (1996). Immunity and the invertebrates. Sci Am 275:60-63.

Castillo J, Teles M, Mackenzie S, Tort L (2009) Stressrelated hormones modulate cytokine expression in the head kidney of gilthead seabream (Sparus aurata). Fish Shellfish Immunol 27:493-499.

Clark WR, Walsh CM, Glass AA, Hayashi F, Matloubian M, Ahmed R (1995) Molecular pathways of CTL-mediated cytotoxicity. Immunol Rev 146:33-44.

Crowe JE Jr (1999) Host responses to respiratory virus infection and immunization. Curr Top Microbiol Immunol 236:191-214.

Deivasigamani B (2007) Structure of immune organ in edible catfish, Mystus gulio. J Environ Biol 28:757-764.

Drummond IA, Majumdar A, Hentschel H, Elger M, Solnica-Krezel L, Schier AF, Neuhauss SC, Stemple DL, Zwartkruis F, Rangini Z, Driever W, Fishman MC (1998) Early development of the zebrafish pronephros and analysis of mutations affecting pronephric function. Development 125:4655-4667.

Du Pasquier L (2001) The immune system of invertebrates and vertebrates. Comp Biochem Physiol B Biochem Mol Biol 129:1-15.

Elward K, Gasque P (2003) "Eat me" and "don't eat me" signals govern the innate immune response and tissue repair in the CNS: emphasis on the critical role of the complement system. Mol Immunol 40:85-94.

Fearon DT (1997) Seeking wisdom in innate immunity. Nature 388:323-324.

Fearon DT, Locksley RM (1996) The instructive role of innate immunity in the acquired immune response. Science 272:50-53.

Grossman WJ, Verbsky JW, Barchet W, Colonna M, Atkinson JP, Ley TJ (2004) Human T regulatory cells can use the perforin pathway to cause autologous target cell death. Immunity 21:589-601.

Henkart PA (1994) Lymphocyte-mediated cytotoxicity: two pathways and multiple effector molecules. Immunity 1:343-346.

Horton JM, Summers AP (2009) The material properties of acellular bone in a teleost fish. J Exp Biol 212: 1413-1420.

Kimmel CB, Ballard WW, Kimmel SR, Ullmann B, Schilling TF (1995) Stages of embryonic development of the zebrafish. Dev Dyn 203:253-310.

Kimmel CB, Warga RM, Schilling TF (1990) Origin and organization of the zebrafish fate map. Development 108:581-594.

Liu CC, Persechini PM, Young JD (1994) Characterization of recombinant mouse perforin expressed in insect 
cells using the baculovirus system. Biochem Biophys Res Commun 201:318-325.

Lowin B, Hahne M, Mattmann C, Tschopp J (1994) Cytolytic T-cell cytotoxicity is mediated through perforin and Fas lytic pathways. Nature 370:650-652.

Lowrey DM, Aebischer T, Olsen K, Lichtenheld M, Rupp F, Hengartner H, Podack ER (1989) Cloning, analysis, and expression of murine perforin 1 cDNA, a component of cytolytic T-cell granules with homology to complement component C9. Proc Natl Acad Sci USA 86:247-251.

Masson D, Tschopp J (1985) Isolation of a lytic, poreforming protein (perforin) from cytolytic T-lymphocytes. J Biol Chem 260:9069-9072.

Medzhitov R, Janeway CA Jr (1998) An ancient system of host defense. Curr Opin Immunol 10:12-15.

Medzhitov R, Janeway CA Jr (2002) Decoding the patterns of self and nonself by the innate immune system. Science 296:298-300.

Meseguer J, Lopez-Ruiz A, Garcia-Ayala A (1995) Reticuloendothelial stroma of the head-kidney from the seawater teleost gilthead seabream (Sparus aurata L.): an ultrastructural and cytochemical study. Anat Rec 241:303309.

Peters PJ, Borst J, Oorschot V, Fukuda M, Krahenbuhl O, Tschopp J, Slot JW, Geuze HJ (1991) Cytotoxic $\mathrm{T}$ lymphocyte granules are secretory lysosomes, con- taining both perforin and granzymes. J Exp Med 173: 1099-1109.

Sunyer JO, Tort L, Lambris JD (1997) Diversity of the third form of complement, C3, in fish: functional characterization of five forms of C3 in the diploid fish Sparus aurata. Biochem J 326(Pt 3):877-881.

Takeyasu K, Tamkun MM, Renaud KJ, Fambrough DM (1988) Ouabain-sensitive $\left(\mathrm{Na}^{+}+\mathrm{K}^{+}\right)$-ATPase activity expressed in mouse L cells by transfection with DNA encoding the alpha-subunit of an avian sodium pump. J Biol Chem 263:4347-4354.

Tran U, Pickney LM, Ozpolat BD, Wessely O (2007) Xenopus Bicaudal-C is required for the differentiation of the amphibian pronephros. Dev Biol 307:152-164.

Trapani JA, Smyth MJ (2002) Functional significance of the perforin/granzyme cell death pathway. Nat Rev Immunol 2:735-747.

Tschopp J, Nabholz M (1990) Perforin-mediated target cell lysis by cytolytic T lymphocytes. Annu Rev Immunol 8:279-302.

Tsujii T, Seno S (1990) Melano-macrophage centers in the aglomerular kidney of the sea horse (teleosts): morphologic studies on its formation and possible function. Anat Rec 226:460-470.

Wilson A, Held W, MacDonald HR (1994) Two waves of recombinase gene expression in developing thymocytes. J Exp Med 179:1355-1360. 